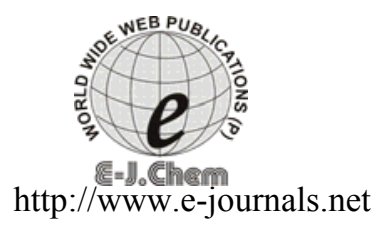

ISSN: 0973-4945; CODEN ECJHAO
E-Journal of Chemistry
2011, 8(S1), S47-S52

\title{
Application of Green Chemistry Principle in Synthesis of Phenytoin and Its Biogical Evaluation as Anticonvulsant Agents
}

\author{
ABHIJIT KADAM ${ }^{*}$, SAMPADA JANGAM and RAJESH OSWAL \\ JSPM's Charak College of Pharmacy and Research \\ Gat No. 720/1\&2, Wagholi, Pune-Nagar Road, Pune-412 207, India \\ sam_jangam@rediffmail.com
}

Received 29 January 2011; Accepted 12 April 2011

\begin{abstract}
Phenytoin (5,5'-dipenylimidazolidine-2,4-dione) is the prime example of anticonvulsant agent. According to reported procedure, it is synthesized by condensation of benzil and urea in presence of base $(30 \% \mathrm{w} / \mathrm{v}$ $\mathrm{NaOH}$ ) using ethanol as solvent which itself acts as CNS stimulant. Removal of solvent after synthesis is most difficult and non-assured process. In case of phenytoin transformation in polymorphism plays an important role when solvent other than water is used. About $30 \%$ extra cost is calculated if solvent other than water is used. Therefore by application of green chemistry principle phenytoin was synthesized by condensation of benzil and urea in presence of base $(30 \% \mathrm{NaOH})$ and water as green solvent. This compound was characterized on the basis of its spectral (IR, ${ }^{1} \mathrm{H}$ NMR) data and evaluated for anticonvulsant activity using MES induced and PTZ induced seizure models in Swiss albino mice. Significant anticonvulsant activity was found by using 25 $\mathrm{mg} / \mathrm{kg}$ and $50 \mathrm{mg} / \mathrm{kg}$ of phenytoin compared with standard phenytoin at 25 $\mathrm{mg} / \mathrm{kg}$ dose.
\end{abstract}

Keywords: Phenytoin, Green chemistry, Green solvent, Anticonvulsant activity

\section{Introduction}

Green chemistry is the design of chemical products and process that eliminates the use and generation of hazardous substances ${ }^{1}$. Using green solvent, like water, synthesis of biologically active moiety with high percentage yield as well as purity is the one of objective of green chemistry. Purity of few drugs like CNS acting required high profile of purity and safety for pertaining biological activity. Synthesis of CNS acting moiety with at par purity could be achieved by omitting interfering solvents. Epilepsy is a common 
neurological condition, affecting 0.5 to $1 \%$ of the population worldwide (45-10 million people $)^{2}$. Epilepsy may be defined as paroxysmal, self-sustaining and self-limiting cerebral dysarrhythmia characterized by an abnormal and excessive electroencephalogram (EEG) discharge and a loss of consciousness. Major types of epilepsies are Generalized seizure and Partial seizure ${ }^{3}$. Phenytoin (5, 5-diphenylimidazolidine-2,4dione) is the first anticonvulsant agent often cited as a prime example of anticonvulsant acting as a sodium channel blocker ${ }^{4,5}$. Generally, according to reported procedure, it is synthesized by condensation of benzil and urea in presence of base $(30 \% \mathrm{w} / \mathrm{v} \mathrm{NaOH})$ using ethanol as solvent which itself acts as CNS stimulant ${ }^{6}$. Removal of solvents after synthesis is most difficult and non-assured process. In case of Phenytoin transformation in polymorphism plays an important role when solvent other than water is used. About $30 \%$ extra cost is calculated if solvent other than water is used. Therefore in present work, Phenytoin was synthesized by condensation of benzil and urea in presence of base $(30 \% \mathrm{NaOH})$ and water, a green solvent and anticonvulsant activity was performed by MES and PTZ induced seizure models.

\section{Experimental}

All the chemicals used for synthesis were of LR (Laboratory Reagent) grade. TLC (Thin Layer Chromatography) was performed on microscopic glass slides $(2 \times 7.5 \mathrm{~cm})$ coated with silica gel-G, using chloroform: ethyl acetate (7:3) as a solvent systems and the spots were visualized by exposure to iodine vapours. The IR spectrum of synthesized compound was recorded on Shimadzu 8400-S FT-IR Spectrophotometer using potassium bromide. The ${ }^{1} \mathrm{H}$ NMR was recorded in DMSO-D6 using NMR Varian-Mercury $300 \mathrm{MHz}$ spectrometer and chemical shifts are given in parts per million, downfield from tetramethylsilane (TMS) as an internal standard from University of Pune.

\section{Synthesis of 5, 5'-dipenylimidazolidine-2,4-dione}

\section{General procedure}

$5.3 \mathrm{~g}(0.025 \mathrm{~mol})$ of benzil, $3 \mathrm{~g}(0.05 \mathrm{~mol})$ of urea, $15 \mathrm{~mL}$ of $30 \% \mathrm{w} / \mathrm{v}$ sodium hydroxide solution and $40 \mathrm{~mL}$ of water was placed in a $250 \mathrm{~mL}$ round bottom flask and refluxed for 2 hours. After cooling to room temperature, the reaction mixture was poured into $100 \mathrm{~mL}$ of water with stirring. It was allowed to stand for 15 minutes and filtered under suction to remove the insoluble by-product. The filtrate thus obtained was cooled and acidified by using concentrate hydrochloric acid. The precipitates obtained were separated by filtration. The crude product obtained was washed with cold water. IR and ${ }^{1} \mathrm{H}$ NMR spectra of synthetised phenytoin are represented by Figure 1 and Figure 2 respectively. The physical and spectral data matched with that of standard given in Table 1, 2 and 3 respectively.

Table 1. Physical data of phenytoin

\begin{tabular}{cll}
\hline S. No. & \multicolumn{1}{c}{ Parameters } & \multicolumn{1}{c}{ Results } \\
\hline 1 & Color, state & Colorless, crystalline \\
2 & Percentage Yield, \% & 44 \\
3 & TLC & (Chloroform: Ethyl acetate), (7:3) \\
4 & R $_{\mathrm{f}}$ Value & 0.64 \\
5 & Melting point, ${ }^{0} \mathrm{C}$ & $296-297(297-298)$ \\
\hline
\end{tabular}




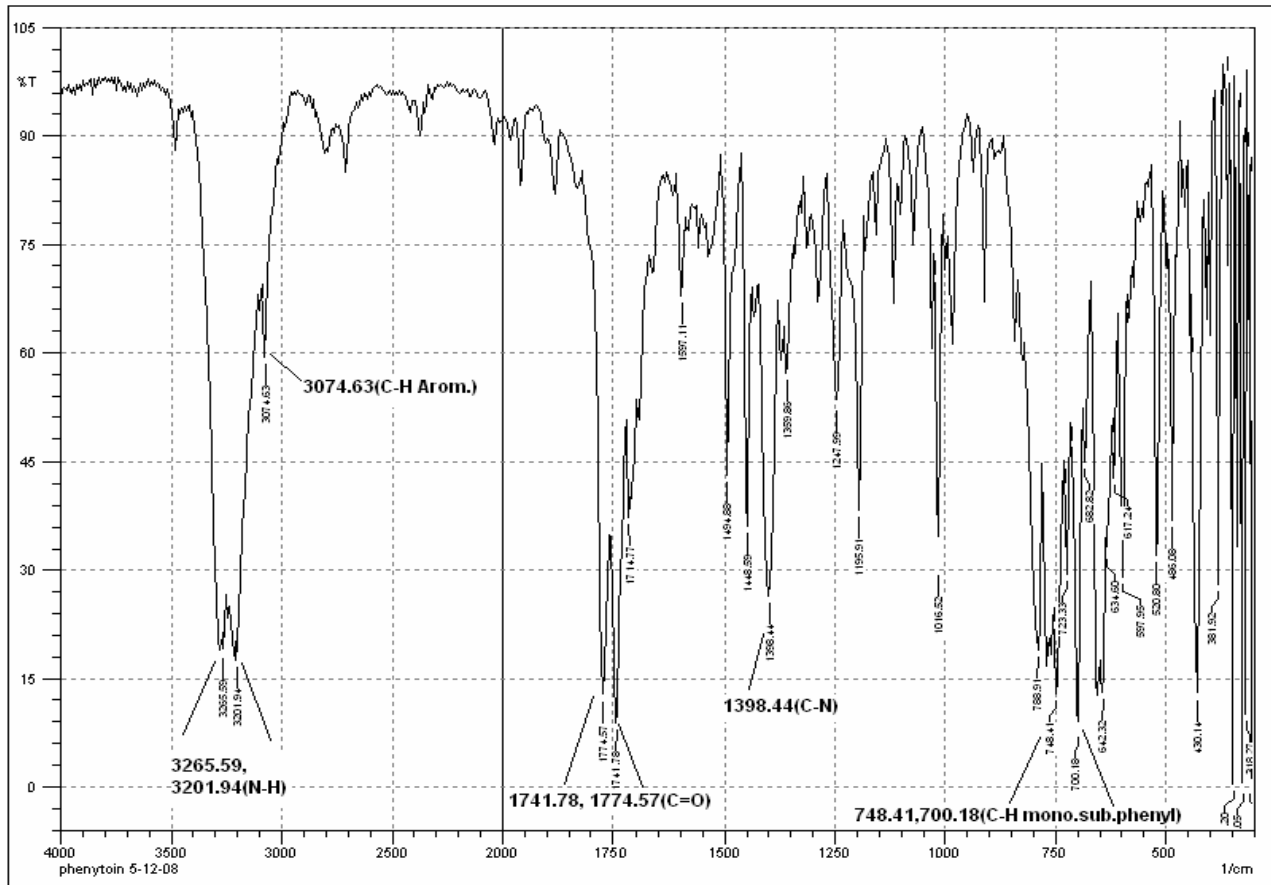

Figure 1. IR $(\mathrm{KBr}) \mathrm{cm}^{-1}$ spectrum of synthesized phenytoin

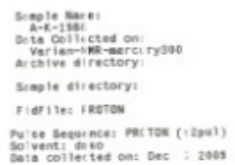

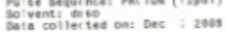

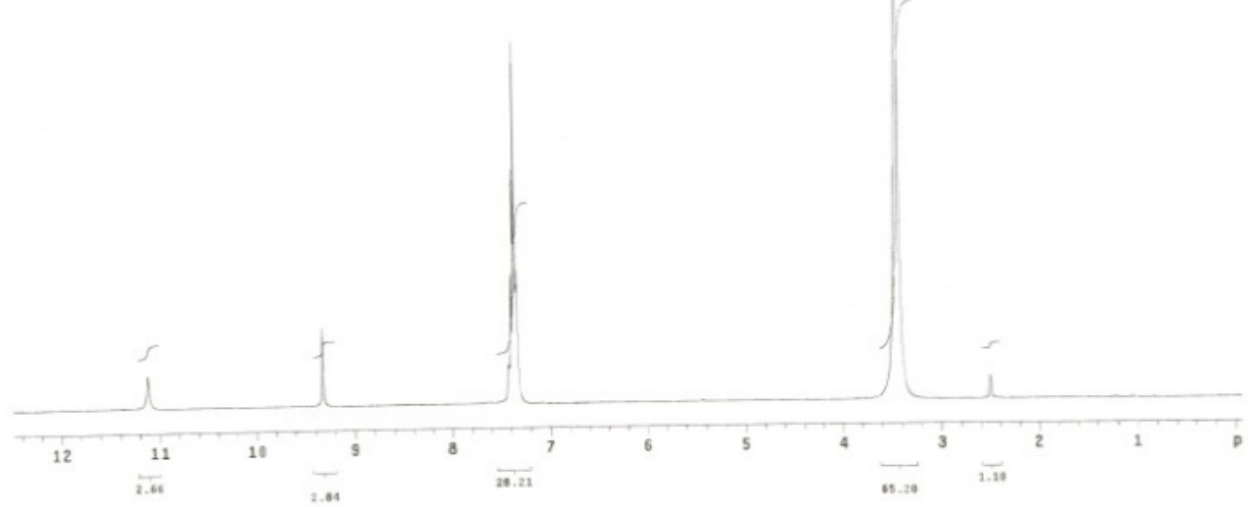

Figure $2{ }^{1} \mathrm{H}$ NMR spectrum of synthesized phenytoin in DMSO D6 
Table 2. IR Spectral data of phenytoin

\begin{tabular}{cll}
\hline S. No. & \multicolumn{1}{c}{ Functional groups } & \multicolumn{1}{c}{$\mathrm{IR}(\mathrm{KBr}) \mathrm{cm}^{-1}$} \\
\hline 1 & C-H Out of plane vibrations of mono- & \\
& substituted phenyl ring & $748.41,700.18$ \\
2 & C-N Stretching & 1398.44 \\
3 & C=O stretching & $1741.78,1774.57$ \\
4 & C-H Stretching of aromatic ring & 3074.63 \\
5 & N-H Stretching & $3265.59,3201.94$ \\
\hline
\end{tabular}

Table 3. ${ }^{1} \mathrm{H}$ NMR spectral data of phenytoin

\begin{tabular}{cll}
\hline S. No. & No. of protons & Chemical shift $(\delta)$ \\
\hline 1 & $(1 \mathrm{H}), s$ & 11.12 \\
2 & $(1 \mathrm{H}), s$ & 9.33 \\
3 & $(10 \mathrm{H}), m$ & $7.34-7.42$ \\
\hline
\end{tabular}

\section{Anticonvulsant activity}

The Anticonvulsant activity of the compound was measured by MES (Maximal electroshock) induced seizure test and PTZ (Pentylenetetrazole) induced seizure test.

\section{MES induced seizure test ${ }^{7,8}$}

The Swiss albino mice of either sex weighing 25-30 g were used for the test. They were divided into four groups each containing 6 mice. $0.1 \%$ gum acacia solution was used as a vehicle for preparation of suspension of Phenytoin. Control group was injected with normal saline solution or gum acacia solution $10 \mathrm{~mL} / \mathrm{kg}$ (p.o.). Phenytoin $20 \mathrm{mg} / \mathrm{kg}$ (i.p.) was used as a standard. Each group test 1 and test 2 was treated orally with $20 \mathrm{mg} / \mathrm{kg}$ and $40 \mathrm{mg} / \mathrm{kg}$ (p.o.) of Phenytoin respectively. They all received current of $48 \mathrm{~mA}$ for $2 \mathrm{~s}$ duration through electroconvulsiometer using ear electrodes after $60 \mathrm{~min}$ of oral administration of test formulation. The animals were observed closely for 2 minutes. The duration of tonic flexion and latency of onset of clonus was recorded. A complete abolition of hind limb tonic extension was considered as $100 \%$ protection. The ability to prevent this feature was considered as an indication of anticonvulsant activity. Data of MES induced seizure test of synthesized phenytoin is given in Table 4 and represented with the Figure 3.

Table 4. Data of Anticonvulsant activity of Synthetic Compound Phenytoin on MESinduced seizures in mice.

\begin{tabular}{|c|c|c|c|c|c|}
\hline \multirow{2}{*}{ S. No. } & \multirow{2}{*}{ Groups } & \multirow{2}{*}{$\begin{array}{l}\text { Dose } \\
\mathrm{mg} / \mathrm{kg}\end{array}$} & \multicolumn{3}{|c|}{ Latency of Onset of phases Time, s } \\
\hline & & & Tonic flexion & Tonic extension & Clonus \\
\hline 1 & Control & Saline water & 0.00 & $11.92 \pm 673$ & $15.49 \pm 432$ \\
\hline 2 & $\begin{array}{l}\text { (Std. Drug) } \\
\text { Phenytoin }\end{array}$ & 25 & $4.83 \pm 0.412^{* * *}$ & $2.10 \pm 514^{* * *}$ & $9.00 \pm 656^{* *}$ \\
\hline 3 & $\begin{array}{l}\text { Test } \\
\text { Compound }\end{array}$ & $\begin{array}{l}25 \\
50\end{array}$ & $\begin{array}{l}2.83 \pm 0.329^{* * *} \\
3.15 \pm 0.231^{* * *}\end{array}$ & $\begin{array}{l}5.00 \pm 0.231^{* * *} \\
2.83 \pm 231^{* * *}\end{array}$ & $\begin{array}{l}13.21 \pm 0.129^{*} \\
10.26 \pm 984^{* *}\end{array}$ \\
\hline
\end{tabular}




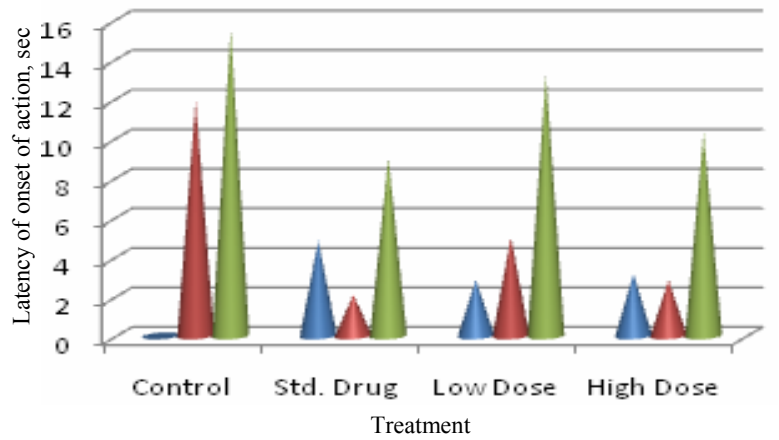

Figure 3. MES induced test on mice of synthetic compound Phenytoin after oral administration (Where As Control group - Saline water, Std. Drug - Phenytoin $25 \mathrm{mg} / \mathrm{kg}$, Test compound phenytoin,. Low dose- $25 \mathrm{mg} / \mathrm{kg}$, High dose- $50 \mathrm{mg} / \mathrm{kg}$ body wt. of Swiss albino mice; Series 1 - tonic flexion, series 2- tonic extension, series 3- clonic phase PTZ induced seizure test ${ }^{9}$ )

Swiss albino mice of either sex with a body weigh between $18 \& 12 \mathrm{~g}$, were used the test compound or the reference drug was injected subcutaneous or Intraperitoneal or given orally two group of 10 mice. Another group of 10 mice serve as control 15 min after oral administration subcutaneously injection $30 \mathrm{~min}$ after intraperitoneal injection or $60 \mathrm{~min}$, after oral administration, $60 \mathrm{mg}$ per $\mathrm{kg}$ PTZ was injected subcutaneously. Each animal was placed in to an individual plastic cage, for observation lasting in seizures and tonic clonic convulsion was recovered. At least $80 \%$ of the animals in the control group were show to convulsion. Data of PTZ induced seizure test is given in Table 4 and represented with the Figure 4.

Table 4. Data of anticonvulsant activity by PTZ-induced seizures in mice

\begin{tabular}{ccccc}
\hline Groups & Dose mg/kg & $\begin{array}{c}\text { Onset of seizures, } \\
\min \end{array}$ & $\begin{array}{c}\text { Onset of death, } \\
\text { min }\end{array}$ & $\begin{array}{c}\text { \% inhibition of } \\
\text { onset of death, \% }\end{array}$ \\
\hline Control & Saline water & $2.89 \pm 0.239$ & $5.21 \pm 0.321$ & 0 \\
Phenytoin Std. & 25 & $6.36 \pm 0.872^{* *}$ & $13.22 \pm 0.641^{* *}$ & 73.69 \\
Phenytoin Test & Low Dose 25 & $6.33 \pm 0.231^{*}$ & $9.36 \pm 0.683^{* *}$ & 61.23 \\
& High Dose 50 & $7.58 \pm 0.1302^{* *}$ & $10.91 \pm 0.456^{*}$ & 69.52 \\
\hline
\end{tabular}

(Values are expressed as mean \pm S.E.M. $n=6{ }^{* *} p<0.01{ }^{*} p<0.05$ compared with vehicle control ANOVA followed by Dunnet's t- test)

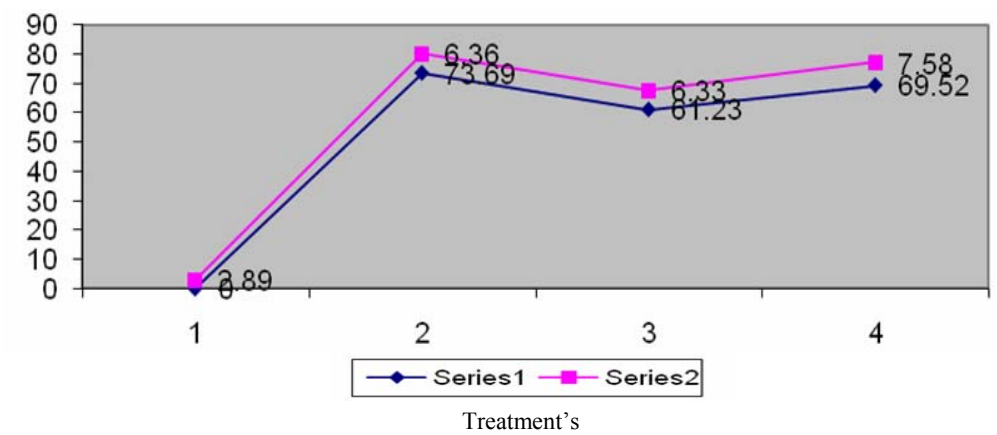

Figure 4. PTZ induced test on mice of Synthetic compound Phenytoin after oral administration 


\section{Results and Discussion}

Phenytoin (5,5'-dphenylimidazoldine-2,4-dione) was synthesized by condensation of benzil and urea in presence of $30 \% \mathrm{NaOH}$ solution and water as a green solvent. It was obtained as a solid melting in the range $296-297{ }^{\circ} \mathrm{C}$. The solid state IR $\left(\mathrm{KBr}, \mathrm{cm}^{-1}\right)$ spectrum of the compound reveals a characteristic aromatic stretch at $3074.63 \mathrm{~cm}^{-1}$. Sharp N-H stretching vibrations are seen at 3265.59 and $3201.94 \mathrm{~cm}^{-1}$. The stretching vibrations of $\mathrm{C}=\mathrm{O}$ group are seen around at 1741.78 and $1774.57 \mathrm{~cm}^{-1}$. The ${ }^{1} \mathrm{H}$ NMR (DMSO, ppm) data of the compound reveal a signal between 7.34-7.42 for the aromatic protons. Presence of characteristic singlet at 9.33 and 11.12 assigned to protons attached to imide and amide nitrogen respectively.<smiles>O=C(C(=O)c1ccccc1)c1ccccc1</smiles>

Benzil
$(0.025 \mathrm{~mol})$<smiles>NC(N)=O</smiles><smiles>O=[W]O[14CH2]O</smiles>

Urea

$(0.05 \mathrm{~mol})$<smiles>O=C1NC(=O)C(c2ccccc2)(c2ccccc2)N1</smiles>

Phenytoin 5,5'-dphenylimidazoldine-2,4-dione

The compound has shown significant anticonvulsant activity with increase latency of onset of phases in Time (s) as compared to standard in MES induced seizure test. PTZ induced seizure test have shown $61.23 \%$ and $69.52 \%$ inhibition of onset of death.

\section{Conclusion}

Phenytoin is synthesized by application of principle of green chemistry with high purity profile as well as having safety by omitting the use of ethanol. Water a green solvent is used instead of ethanol in synthesis of phenytoin. There is reduction in time and ultimately cost as compare to conventional procedure of synthesis of phenytoin. Thus we conclude that the synthesized compound have potential in the green chemistry.

\section{Acknowledgment}

Thanks to serum institute, Hadapsar, Pune (India) for providing the animals for biological evaluation. Thanks to university of Pune, Pune (India) for providing us facility for NMR interpretation.

\section{References}

1. Kidwai M, Green Chemistry in India; Pure Appl Chem., 2001, 73, 1261-1263.

2. Bell G S and Sander J, Seizure, 2002, 11 (Suppl. A), 306-314.

3. Tripathi K D, Essentials of Medical Pharmacology; Jaypee Publications: New Delhi, 2003, 495-498.

4. Bigge C and Boxer P, Annu Rep Med Chem., 1994, 29, 13-22.

5. Wong M G, Defina J A and Andrews P R, J Med Chem., 1986, 29, 562-572

6. Furniss B, Hannaford J, Smith P W G and Tatchell A R, Vogel's Textbook of Practical Organic Chemistry; $5^{\text {th }}$ Edition Dorling Kindersley: New Delhi, 2008, 1153.

7. Vogel H, Drug discovery and Evaluation Pharmacological Assays: Springer Publication: Berlin, 2002, 422.

8. Achliya G S, Wadodkar G S and Dorle A K, J Ethnopharmacolo., 2004, 94(1), 77-83

9. Nguelefack T B and Astamo A D, J Ethnopharmacolo., 2006, 106, 70-75. 


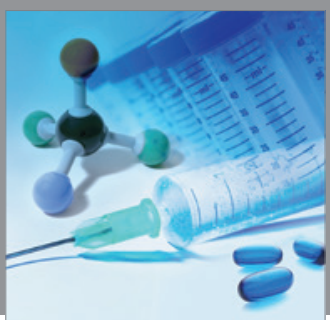

International Journal of

Medicinal Chemistry

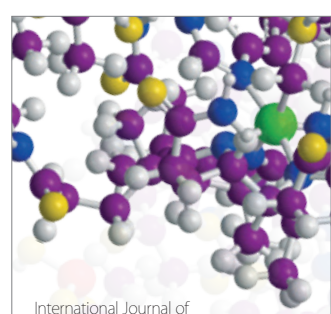

Carbohydrate Chemistry

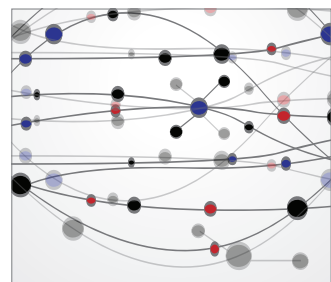

The Scientific World Journal
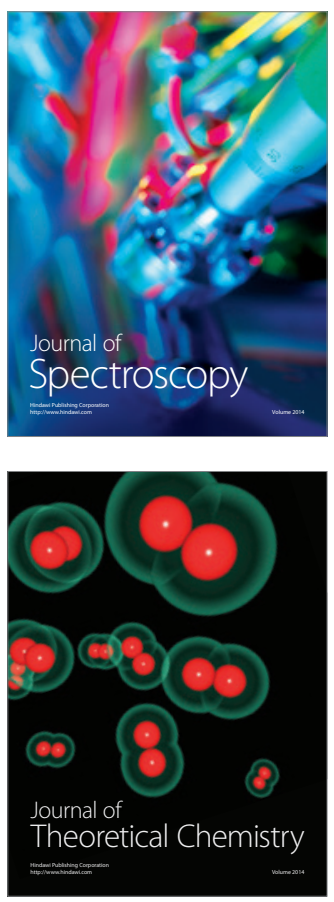
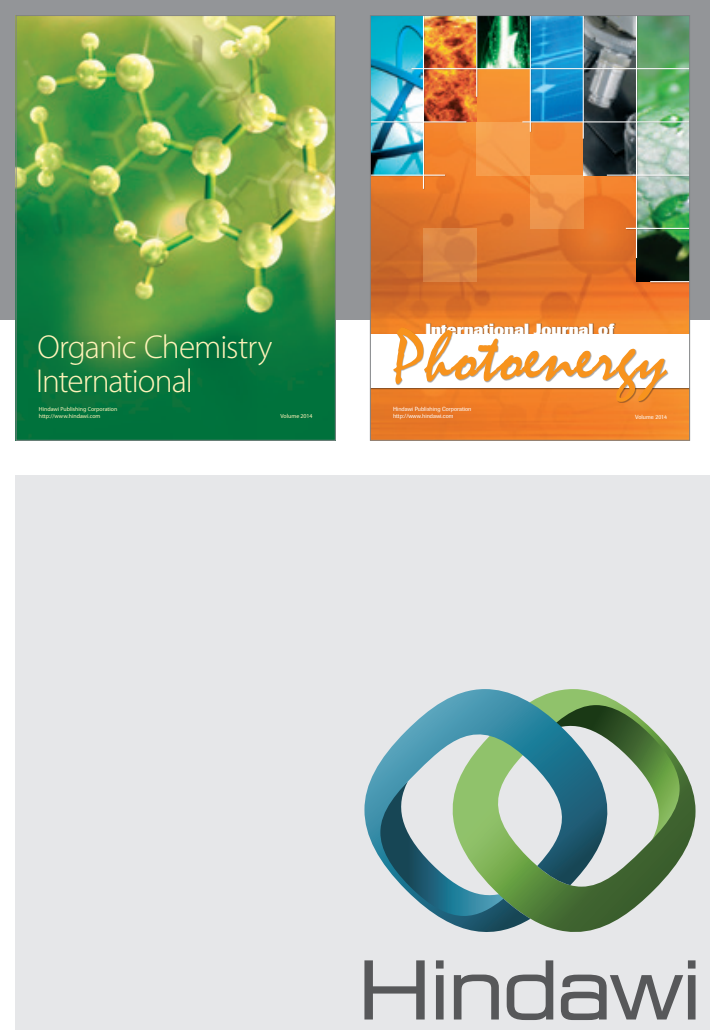

Submit your manuscripts at

http://www.hindawi.com
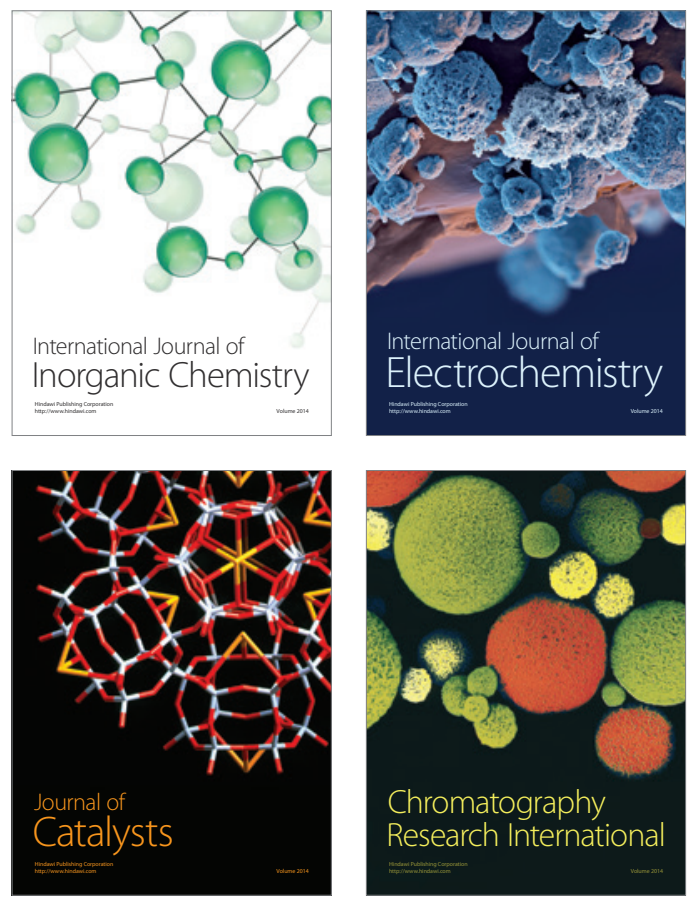
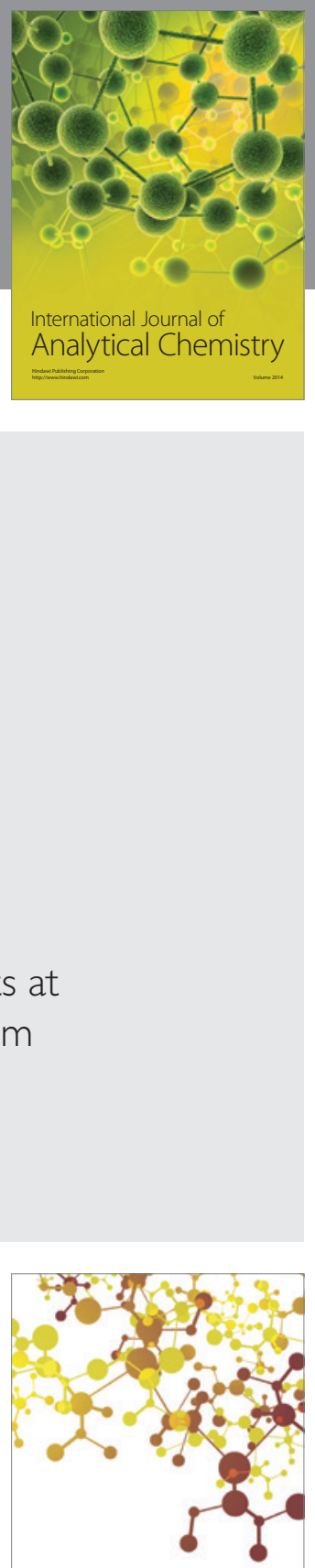

Journal of

Applied Chemistry
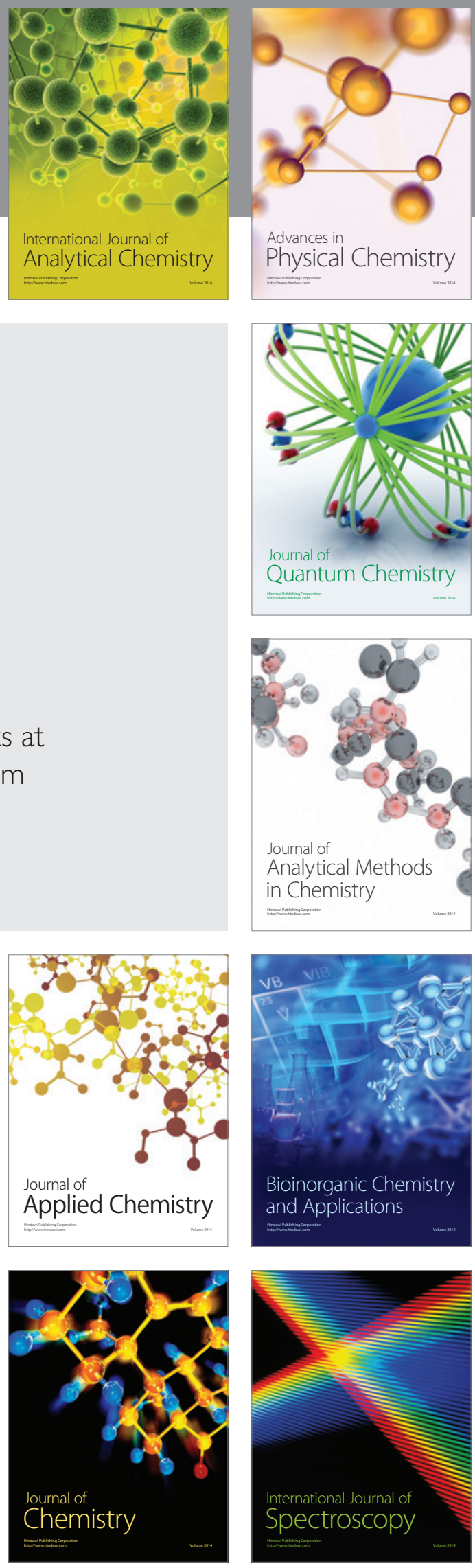